\title{
WOMEN DIRECTORS ON TOP UK BOARDS
}

\author{
Val Singh, Susan Vinnicombe and Phyl Johnson \\ Centre for Developing Women Business Leaders \\ Cranfield School of Management, \\ Cranfield University, \\ Bedford MK43 OAL \\ UK \\ Tel: $+44(0) 1234751122$ Ext 3192 \\ Fax: +44 (0)1234 751806 \\ email: v.singh@cranfield.ac.uk
}

\begin{abstract}
Research suggests that more diversity in board membership could improve overall performance. This paper considers the business case for increased numbers of female directors, and the lack of female representation on UK FTSE 100 company boards in 1999 and 2000. It also offers a comparison to US data. In 1999, almost two-thirds of FTSE 100 companies had at least one female director, but numbers had dropped by July 2000 from $64 \%$ to $58 \%$, paralleling the levelling-off at top level reported in North America. More firms having female directors are to be found amongst those with the highest turnover, profit and number of employees in the FTSE 100, again paralleling the findings from the US.
\end{abstract}

\section{Introduction}

Diversity on boards is said to provide better corporate governance through the sharing of a broader and different range of experiences and opinions. However, most boards of large companies are homogeneously constituted, by white, middle class, middle-aged males with similar educational and professional backgrounds. There are few female directors, and even fewer female executive directors. Only one woman, Marjorie Scardino of Pearson, the media/publishing company, made it to CEO in the FTSE 100 list, and she was the only woman in the recent list of FTSE 100 directors paid more than $£ 1 \mathrm{~m}$ in 1999 (The Guardian, 2000). There is still a long way to go.

\section{Diversity in the Boardroom}

Lorsch and Mclver (1989) uncovered widespread stagnation in the boardroom, where there was often lack of freedom to express ideas, and routines even extended to where individual directors sat in board meetings. In their meta-analysis of boardroom studies, Dalton, Daily, Ellstrand and Johnson (1998) identified the two major issues affecting performance in the boardroom as power imbalance resulting from board composition, and the CEO/Chairman role.

Charan (1998) and others (Westphal and Zajac, 1995) focused on diversity in board composition as an area in need of reform. As Norburn's (1989) study of UK CEO's demonstrated, the pool from which CEOs and board members are drawn can be extremely small, operating as an elite 'old boys' network. There was only limited evidence of demographic diversity in the boardroom according to Westphal (1998). He found that board members did not usually want to rock the boat, and their CEOs often used tactics to achieve their own personal goals. It would appear that the primary means of conflict avoidance employed in the boardroom is homogeneous composition. However, group work research demonstrates that homogeneity in group composition does not necessarily lead to high performance, and in fact, team diversity was found to lead to better 
performance by Maznevski (1994). Moreover, a study of board interconnectedness or interlocking directorships (MacCanna, Brennan and O'Higgins, 1999) uncovered negative performance implications for boards drawing from a small pool of non-diverse individuals for new members. But changing the environment of the corporate board to become more diverse, as recommended by Maznevski and by Charan means that the interlocking nature of board appointments from a small exclusive group of individuals would need to be dismantled. Such a change would be a major challenge for the corporate boards of today. One way to achieve this would be to increase gender diversity on corporate boards.

\section{The Business Case for Gender Diversity}

Bilimoria (2000a) makes a strong business case for gender diversity on corporate boards. In the Fortune 500 listed companies, overall financial status was higher in the most profitable 50 of the 500 companies which also happened to have female directors. It could be that the presence of female directors was linked to overall financial status, but it might simply be that when the largest companies became more profitable, they were more open to diverse appointments. Bilimoria found that females were often appointed as additional rather than replacement directors. Corporate reputations were enhanced by the visible presence of women on the board, and some major investors (such as large pension funds) showed a preference to invest in firms demonstrating diversity in board appointments (Kuczynski, 1999).

Bilimoria argues that women directors have an impact on board decision-making, with fresh and often well-informed views on market, environmental and ethical issues. A good example of this was the suggestion by a female director of Nike that they should introduce sports shoes designed especially for women. This created a whole new market as women's sports- and footwear became fashionable and colour-coordinated. Fondas and Sassalos (2000) showed that boards with one or more female directors had significantly more influence over management decisions. They suggested that women were more able to influence corporate governance because of their broader experiences and different "voice", and that boards with even just one woman director would be less likely to rubberstamp CEO decisions.

Women's presence in the boardroom is said to lead to more civilised behaviour and sensitivity to other perspectives, as well as a more interactive and transformational board management style (Rosener, 1990). The presence of women at such senior levels encourages those women lower down in the management hierarchy. Research is currently examining whether women managers benefit from the presence of female directors (Bilimoria, 2000b). The existence of female board members may have a positive effect on the recruitment, retention and representation of women (Ragins, Townsend and Mattis, 1998).

\section{Women Directors - International Research Comparisons}

Given increasing numbers of women in managerial positions, there should be a pool of women with the potential to attain board positions, leading to more heterogeneous board composition. However, although the number of women in management has increased in the UK since the launch of the Opportunity 2000 initiative in 1991, few females have yet reached the very top levels of the largest corporations (Holton, 2000). In North America, the glass ceiling of the 1980s has simply shifted up through the organisation to the uppermost echelons (Burke and Mattis, 2000). Daily, Certo and Dalton (1999) showed there was a significant lack of women on Canadian and US corporate boards, and noted that even when women were appointed to US boards, it was almost always as outside directors (equivalent to UK non-executive positions). Women were failing to make it to CEO positions, and the already minimal female CEO figures had actually reduced from 11 in 1987 to 8 female Fortune 500 CEOs in 1996. 
Bilimoria and Piderit (1994) argue that women are quite literally being kept out of the spotlight. Clearly, women face a number of additional hurdles compared to men to reach the top. These include greater efforts needed to find appropriate mentors (Ibarra, 1992), and difficulties in gaining senior sponsorship or promotion because of demographic similarity preferences held by senior males (Varma and Stroh, 1998). There is the need for greater visibility and "political seasoning" (Mainiero, 1994), and there is the tendency for females to be protected from or not allocated to the most challenging assignments (Ohlott, Ruderman and McCauley, 1994). In particular, women face difficulties in gaining international experience, increasingly thought essential for the path to CEO (Daily, Certo and Dalton, 2000).

Burke (1997) reports that the dominant reason for lack of progress is uncertainty by senior directors about female executives' ability to perform at this level due to lack of business and corporate experience. The most common ways for women's names to be brought to the CEO's attention were recommendations from board members and being known personally to the CEO. CEOs believed that there were extremely few women who met the criteria for appointment, and had difficulty in finding appropriate candidates. Similar findings are reported by Ragins, Townsend and Mattis (1998). These reasons imply need for better upward networking by women, who tend to be less instrumental than men in initiating and maintaining upwards relationships (Ibarra, 1992; Vinnicombe, Singh and Sturges, 2000).

\section{Previous Research on UK Women Directors}

A Hansard Society Commission report (McRae, 1995) showed that only $6 \%$ of 120 firms in The Times "Top 200" companies had female executive main board directors. Women comprised only $1 \%$ of executive directors overall, up from $0.5 \%$ in 1989 , and had increased their percentage of non-executive positions from 3.9\% in 1989 to $10.4 \%$ in 1995 . Again, the major barrier for women's non-executive appointments was perceived lack of corporate board experience.

The Tavistock/Change Partnership (1999) reported that in a selection of companies (from the FTSE 100, the public sector, professional service firms, and not-for-profit organisations), women held less than $3 \%$ of executive directorships. Progress had been made in the public sector, women now making up $48 \%$ of first line Civil Service managers, compared to $29 \%$ in 1984 . Women comprised $18 \%$ of the senior-most grade. But the authors' view was that the "trickle up" theory of women waiting in the wings for advancement to top directorships was dramatically disproved by their research.

Similar trends were reported by Opportunity Now (Maitland, 2000). The percentage of female executive directorships in the 59 Opportunity 2000 member companies dropped from $10 \%$ in 1998 to $8 \%$ in 1999, and female non-executive directorships dropped from $20 \%$ to $14 \%$ in 1999 . However, at lower levels, the trend was still upwards, with the proportion of women middle managers in the private sector rising from $27 \%$ to $33 \%$, and for junior managers, $40 \%$ rising to $45 \%$ in 1999.

The British national press (Bell, 1999; Oldfield, 2000a) often suggests that internet companies may open the door for women, as this new industry does not have such an entrenched male-dominated culture. Much of this optimism is based on a few highly publicised internet business deals with women as co-founders, and may not be sustained. There are now more women directors in SMEs, and younger women seem to be making headway. More than $37 \%$ of directors aged between 18 and 24 are women, though $95 \%$ of the SMEs in the study have less than $£ 5 \mathrm{~m}$ annual sales. Oldfield (2000b) reported a study 
by Experion which found that $32 \%$ of UK directors in their sample were female in 1998, rising to $33.1 \%$ in 1999 , an actual increase of 3000 women in director positions.

The figures are difficult to compare, even within the UK as different sets of companies are involved. The US data on Fortune 500 boards is more consistent and it would be useful to have comparable data for companies selected on similar criteria each year. This study therefore seeks to update figures for women on corporate boards of FTSE 100 companies in the UK, put them into an international context, and consider the implications for further research.

\section{Methods}

A database listing of the FTSE 100 companies was obtained from "One Source Data" on 14 July 1999. The FTSE 100 is a Financial Times/London Stock Exchange index of the largest 100 companies listed on the London Stock Exchange, providing a day-by-day indication of how the market is changing and the positioning of companies within it. We identified companies with female directors, and telephoned company secretaries to check the information gathered. A further check was made of FTSE 100 companies' annual reports and websites, to obtain biographical details of directors. One year later, on $31^{\text {st }} \mathrm{July}$ 2000, the FTSE 100 list of companies was taken again, using the database service of The Financial Times.

\section{Changes in Composition of the FTSE 100}

As expected, there were some changes in the companies forming the FTSE 100 a year later. Thirteen companies entered the list, of which only five had women directors. Similarly, Burke and Mattis (2000) found that those entering the Fortune 500 list were more likely to have no women directors. One company with two female directors left the FTSE 100 after a takeover. The situation is fluid at present, as new sectors such as e-commerce start to enter the FTSE 100. The percentage of companies with female directors has gone down in the last twelve months. Appendix 1 shows the companies listed in July 2000.

\section{Findings: Women on FTSE 100 Boards in 1999 and 2000}

In July 1999, 64\% of the FTSE 100 companies had at least one female director, but this went down to $58 \%$ by July 2000. Table 1 gives the statistics for 1999 and 2000.

Table 1: FTSE 100 Company Board Statistics, 1999 and 2000

\begin{tabular}{lcc}
\hline FTSE 100 Company Statistics & July 1999 & July 2000 \\
\hline Companies with no female directors & 36 & 42 \\
Companies with at least one female director (executive and/or non-executive) & 64 & 58 \\
Companies with at least two female directors (executive and/or non- & 13 & 12 \\
executive) & 1 & 1 \\
Companies with a female CEO & 12 & 10 \\
Companies with female executive directors & 1 & 1 \\
Companies with two female executive directors & 16 & 14 \\
Companies with female company secretaries & 25 & 16 \\
Companies with at least two women in the boardroom, including & & 1 \\
Companies with three wometaries in the boardroom, including directors & 2 & \\
and company secretaries & & \\
\hline
\end{tabular}

Only one company, Pearson, had a female CEO, Marjorie Scardino, and only the Woolwich had two female executive directors in both years. In 1999, Kingfisher and Pearson each had two female directors and a female company secretary, whilst by 2000 , 
only Pearson had three women in the boardroom. In 1999, BSkyB was the only FTSE 100 company to have three female directors, although one was an "alternative" director, so there were three females only occasionally. Whilst $13 \%$ had two female directors in 1999, this went down to 12\% in 2000 (Abbey National, Astra Zeneca, Barclays, BT, Granada, Legal \& General, Marks \& Spencer, Pearson, Prudential, Smithkline Beecham, Telewest and Woolwich). In 1999, 9\% had a female director and a female company secretary (BAA, BOC, British Airways, BP Amoco, Centrica, Orange, Shell, United News and WPP), reducing to 4\% in 2000 (BAA, BP Amoco, Kingfisher and WPP). Twenty-five companies in 1999 had at least two females in the boardroom (female directors and/or company secretary), compared to only 16 companies in 2000 . Seven companies in 2000 had female company secretaries but no female directors, making the total of companies with women (rather than directors) in the boardroom up to $65 \%$.

\section{Sectors with Women Directors}

Sectors where women directors were likely to be found were retail, especially grocery; savings institutions (supporting the Sunday Times report (Oldfield, 2000) that $44 \%$ of all female directors work in banking, finance or insurance); health; media and publishing, and utilities. This compares to US Fortune 500 companies, where female directors were most likely in toys and sporting goods, soaps and cosmetics, savings institutions and media/publishing (Catalyst, 1999).

\section{Female Directors and Directorships}

Table 2 gives figures for 1999 and 2000, where a drop is shown this year.

Table 2: FTSE 100 Female Directorship Statistics

\begin{tabular}{lcc}
\hline Female Directorships in FTSE 100 Companies & July 1999 & July 2000 \\
\hline Total number of female directorships & 79 & 69 \\
Female executive directorships & 13 & 11 \\
Female non-executive directorships & 66 & 58 \\
Total percentage of female directorships & $6.29 \%$ & $5.81 \%$ \\
Percentage of executive directorships held by females & $2.02 \%$ & $1.99 \%$ \\
Percentage of non-executive directorships held by females & $10.82 \%$ & $9.13 \%$ \\
\hline
\end{tabular}

Table 3: FTSE 100 Female Director Statistics

\begin{tabular}{lcc}
\hline Female Directors in FTSE 100 Companies & July 1999 & July 2000 \\
\hline Number of females holding directorships in FTSE 100 & 67 & 60 \\
Number of females holding two FTSE 100 directorships & 10 & 7 \\
Number of females holding three FTSE 100 directorships & 1 & 1 \\
Number of females directorships held by females with titles (Baroness, & 26 & 22 \\
Lady, Dame, Professor, Dr) & & \\
\hline
\end{tabular}

Company reports give the date of first appointment of directors. The data were examined to see when the women directors in the 1999 FTSE 100 companies were first appointed. Very few appointments were made during the 1980s, but as shown in Figure 1, this increased to three or four women each year in the first half of the 1990s, suddenly rising to 22 women first appointed in 1998. This parallels the sudden increase in female Labour Party MPs in the 1997 British General Election.

One woman (Baroness Hogg) held three FTSE 100 posts in 1999, whilst ten women held two FTSE 100 directorships. Seven of those had titles (Baroness, Lady, Dame). Of the 79 female directorships, 26 were held by titled women (including Professor and Dr). (See Table 3.) As in the US, there is a preference for well-known "brand-name" women directors, especially those already holding one or more top company directorships, perhaps because CEOs feel that there is less risk than with an unknown woman. 


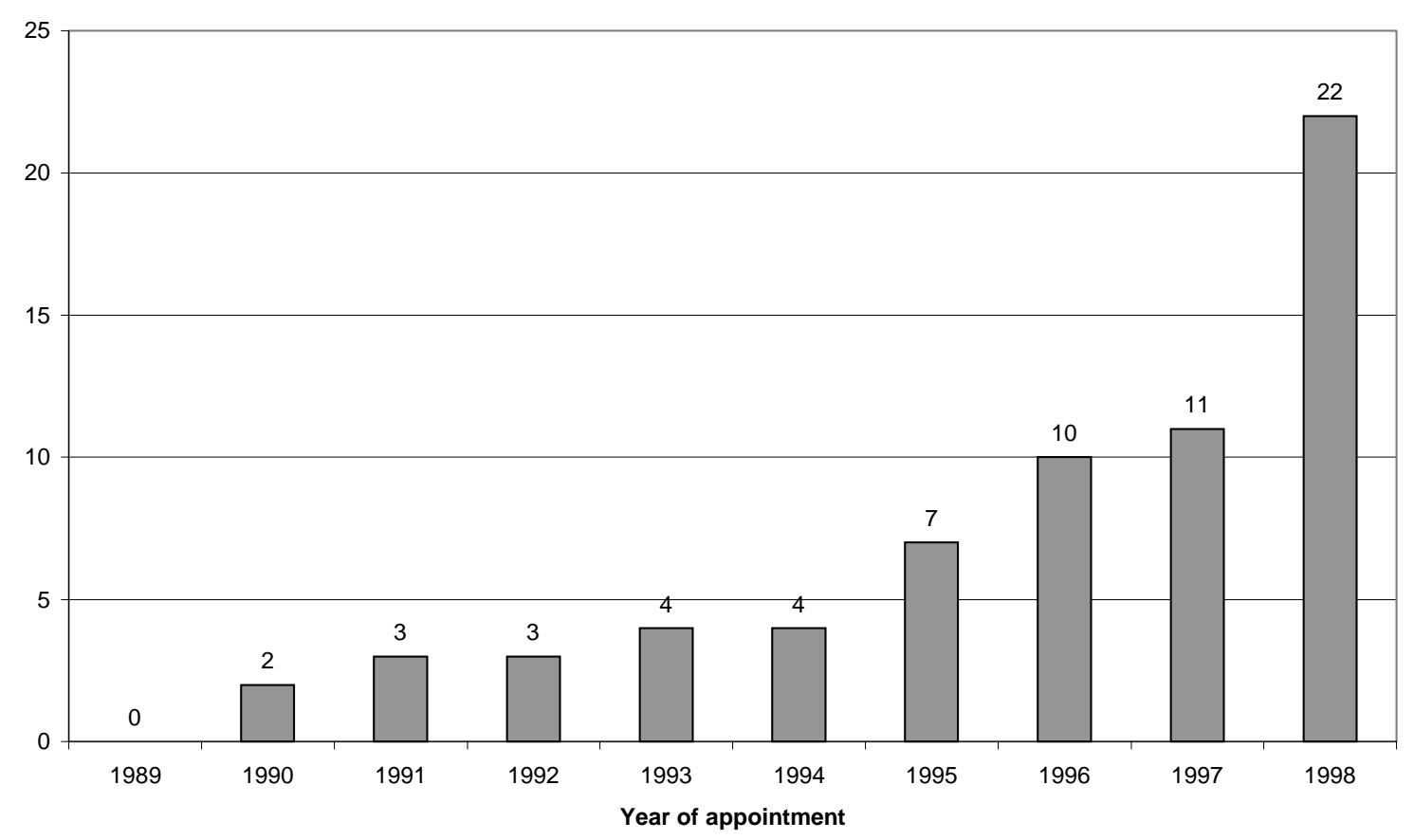

Figure 1: Year of First Appointment of Female Directors in FTSE 100 taken in July 1999

Women held $2 \%$ of all executive positions and $1 \%$ of CEO positions of companies listed in the FTSE 100 Index in 1999 and 2000. The posts which the 13 female executive directors held were Chairman, CEO, Co-Founding Director, two Finance directors; three HR directors; two Operations directors, one alternative director to the CEO, and two company secretary directors. Although dismally low, these figures stand up to comparable US figures (see Table 5). However, job titles and cross-national definitions make it difficult to compare these figures accurately with those, and the numbers are still very small in both countries. If UK company secretaries were also included as holding executive positions in the boardroom (see below), then the figures for females on FTSE 100 boards would be considerably increased from $2.02 \%$ to $4.19 \%$ of executive appointments, in contrast to the Fortune 500 2\%. Catalyst (2000) reported that women held $6.2 \%$ of executive "clout titles" (defined as chairman, chief executive officer, vice-chairman, president, chief operating officer, senior executive vice-president and executive vice-president) in Fortune 500 companies, an increase from $2.4 \%$ in 1995 , though most were EVPs, the lowest rank included.

\section{Female Company Secretaries}

A little publicized route to the board is through a specialist track as company secretary. UK company secretaries act in a similar way to legal directors in the US, and the position has become highly professionalised, with women making inroads into this previously maledominated role. Where the company secretary is female, there is de facto presence of a woman in the boardroom, even if she has not been appointed as a director. She is party to the decision-making, and her professional advice to the board will give her a platform to be heard. Sixteen FTSE 100 company secretaries were female in 1999, including two directors, dropping to $14 \%$ in 2000 . If company secretaries were included as board members, then $25 \%$ of FTSE 100 companies had multiple women on their boards in 1999, dropping significantly to $16 \%$ in 2000 . We also consulted the FTSE 350 Index, finding the percentage of female company secretaries staying around 15\%. Fourteen of the 16 companies with female company secretaries in 1999 also had female directors. Unfortunately, whilst annual reports list the date of director appointments, there is no such practice for the date of appointment of company secretaries. It is therefore not known 
whether the female company secretaries were recruited before or after the female directors. It would be interesting to know if there is any connection between these female board appointments.

Females found in the most profitable companies

We wanted to compare findings with those from Catalyst (1997), who found that the top 100 Fortune firms by revenue were more than twice as likely to have multiple female directors as the bottom 100 firms in the Fortune 500 list. We therefore sorted the July 2000 FTSE 100 companies by size, profit and turnover, and found a similar pattern in the UK data. Female directors were to be found in the bigger, more profitable firms, and particularly those with the largest turnover. See Table 4.

Table 4: FTSE 100 Companies: Number with female directors, by company employee size, profit and turnover.

\begin{tabular}{llll}
\hline $\begin{array}{l}\text { FTSE 100 } \\
\text { at July 2000 }\end{array}$ & $\begin{array}{l}\text { Sorted by Number of } \\
\text { Employes (98 firms } \\
\text { listed info) }\end{array}$ & $\begin{array}{l}\text { Sorted by Size of Profit } \\
\text { (99 firms listed info) }\end{array}$ & $\begin{array}{l}\text { Sorted by Size of } \\
\text { Turnover } \\
\text { (93 firms listed info) }\end{array}$ \\
\hline $\begin{array}{l}\text { Companies with female } \\
\text { directors in Top 50 }\end{array}$ & $\begin{array}{l}34 \\
(68 \% \text { of top 50) }\end{array}$ & $\begin{array}{l}34 \\
(68 \% \text { of top 50) }\end{array}$ & $\begin{array}{l}36 \\
(72 \% \text { of top 50) }\end{array}$ \\
$\begin{array}{l}\text { Firms } \\
\text { AVERAGE \% IN ALL }\end{array}$ & $58 \%$ & $58 \%$ & $58 \%$ \\
$\begin{array}{l}\text { FTSE 100 } \\
\begin{array}{l}\text { Companies with female } \\
\text { directors in Bottom 50 }\end{array}\end{array}$ & $\begin{array}{l}\text { (48\%f lower 50) } \\
\text { Firms }\end{array}$ & $\begin{array}{l}24 \\
(48 \% \text { of lower 50) }\end{array}$ & $\begin{array}{l}22 \\
(44 \% \text { of lower 50) }\end{array}$ \\
\hline
\end{tabular}

Table 5 compares our results with those of Catalyst, where direct comparisons have been possible. Interestingly, the FTSE 100 companies have similar percentages of female executive (inside) directors to the Fortune 500 companies. FTSE 100 figures were $2.0 \%$ in 1999 and 2000 compared to $1.1 \%$ and $2.0 \%$ in the Fortune 500. The US Fortune 500 companies had a large increase of women on boards during the late 1980s and early 1990s, but progress slowed down and even regressed a little during the late 1990s. Mattis (Catalyst, 1999) reports that the figures for the lower half of the Fortune 1000 are considerably lower than for the companies in the top half.

Table 5: Comparison of FTSE 100 Companies and Fortune 500 Companies

\begin{tabular}{|c|c|c|c|c|c|}
\hline & $\begin{array}{l}\text { FTSE } 100 \\
1999\end{array}$ & $\begin{array}{l}\text { FTSE } 100 \\
2000\end{array}$ & $\begin{array}{l}\text { Fortune } \\
500 \\
1997\end{array}$ & $\begin{array}{l}\text { Fortune } \\
500 \\
1998\end{array}$ & $\begin{array}{l}\text { Fortune } \\
500 \\
1999\end{array}$ \\
\hline $\begin{array}{l}\text { Companies with at } \\
\text { least } 1 \text { female } \\
\text { director }\end{array}$ & $\begin{array}{l}64 \\
64 \%\end{array}$ & $\begin{array}{l}58 \\
58 \%\end{array}$ & $\begin{array}{l}420 \\
84 \%\end{array}$ & $\begin{array}{l}429 \\
86 \%\end{array}$ & $\begin{array}{l}419 \\
84 \%\end{array}$ \\
\hline $\begin{array}{l}\text { Companies with } \\
\text { multiple females on } \\
\text { board }\end{array}$ & $\begin{array}{l}13 \% \\
(25 \% \text { if include co } \\
\text { sec's) }\end{array}$ & $\begin{array}{l}12 \% \\
(16 \% \text { if include } \\
\text { co secs) }\end{array}$ & $\begin{array}{l}181 \\
36 \%\end{array}$ & $\begin{array}{l}188 \\
38 \%\end{array}$ & $\begin{array}{l}196 \\
39 \%\end{array}$ \\
\hline $\begin{array}{l}\text { Companies with } 3 \text { or } \\
\text { more females on } \\
\text { board }\end{array}$ & $\begin{array}{l}1 \text { (only if } \\
\text { "Alternative" } \\
\text { female director is } \\
\text { counted) } 1 \% \\
(2 \% \text { if co secs are } \\
\text { included) }\end{array}$ & $\begin{array}{l}0 \\
0 \% \\
\text { ( } 2 \% \text { if co secs } \\
\text { are included) }\end{array}$ & $\begin{array}{l}31 \\
6.2 \%\end{array}$ & $\begin{array}{l}34 \\
6.8 \%\end{array}$ & $\begin{array}{l}45 \\
9 \%\end{array}$ \\
\hline $\begin{array}{l}\% \text { of board seats } \\
\text { held by female } \\
\text { directors }\end{array}$ & $6.3 \%$ & $5.8 \%$ & $10.6 \%$ & $11.1 \%$ & $11.2 \%$ \\
\hline $\begin{array}{l}\text { Female } \\
\text { executive/inside } \\
\text { directorships }\end{array}$ & $2.0 \%$ & $2.0 \%$ & $1.0 \%$ & $1.1 \%$ & $2 \%$ \\
\hline
\end{tabular}




\section{Discussion}

Previous research has established the need for increased diversity on boards to enhance corporate performance. We have reviewed previous research into the numbers of women on UK boards, set this in the context of American studies, and obtained new data from FTSE 100 boards of directors for the years 1999 and 2000. We found that the number of women directors overall in leading UK companies was rising but slowly up to 1999, but that there was a fall in 2000. The small numbers make it difficult to make any statistical inferences from the data, other than that an extremely low level of representation has dropped somewhat over the last twelve months. UK boards have not yet reached the levels of female representation to be found in the US, except for executive director appointments.

However, the key concern of male CEOs in the Hansard Report and the Catalyst studies was women's lack of corporate board experience. It is a Catch 22. How can women gain the corporate board experience to get appointed in the first place? There is a strong trend for well-known women (especially those with titles) to be appointed as non-executive directors in several companies. CEOs could actively encourage the appointment of their pre-director level executive women to their own divisional, regional or subsidiary boards, or where the CEO has appropriate connections, arrange for these women to serve as nonexecutive directors on boards of smaller companies. The women could thereby obtain corporate experience which would enable them to build up appropriate CVs for the top company boards. A good example of this is the gender-balanced BT (UK) Board, chaired by Patricia Vaz, where a number of women directors are gaining useful subsidiary board experience which may later help them overcome this particular hurdle, should they seek and be qualified for more senior board appointments.

There is a serious reason for taking action to redress the gender imbalance at the top of companies now. A trend has been identified by the Conference Board of Canada (Orser, 2000) showing that the most talented women who do find themselves hindered by male preconceptions of limitations of their ability and corporate experience will leave the corporate world. Many will set up their own businesses, or simply readjust their career perspectives. This is not just happening in North America, but also in the UK. Marshall (1995) charted the reasons why a number of senior British women left their successful business careers. Nicholson (2000) also reported Dame Rennie Fritchie as saying "In the UK, women are more pragmatic. ... They will look at the stress, back-stabbing, 20-hour days and say, 'You can keep it!'” Nicholoson cites a number of high profile women leavers, including Penny Hughes, President of Coca-Cola Great Britain, who left to bring up young sons, and Brenda Barnes, CEO of PepsiCo who left again because of managing her work and family life. These were women who were role models and symbols to those waiting in the wings. It may suit existing male-dominated power structures that the most talented women should leave, but their expertise and different perspectives on boardroom issues is likely to be missed.

\section{Limitations}

Whilst we have confidence in our UK data through triple checking (via annual reports, web pages and telephone calls to company secretaries), we have a real problem when it comes to cross national comparisons and repeat surveys. Even a question as simple as "who are the board" is full of difficulties. In Scandinavian countries, for example, companies often have two boards, one headed by the chairman with union and local government representatives, often with high female representation, and the executive board consisting of the heads of functions, chaired by the CEO (Bilimoria and Huse, 1997). We compare inside and outside directors of US companies to executive and non-executive directors in the UK, but there are differences. Should non-executive chairmen and deputy chairmen be 
counted when comparing women in positions of power cross-nationally? Should UK company secretaries be counted as directors when they sit on the board, as their equivalent "legal directors" in US companies would be counted? Should "alternative directors" be counted if female, even if they operate only infrequently? Where numbers are so low, differences may be accounted for by different definitions for inclusion in the data.

There are other limitations to comparisons, for example, the number of board places overall. Board sizes were broadly similar in the UK and US on average, around 10-12 (findings of this study and Catalyst, 1999), whilst in Australia, there are more likely to be only eight board members (Burgess, 2000). In the UK, boards are often balanced between executive and non-executive directors, in the US there is a trend for fewer inside directors, and in Australia, around $80 \%$ of directors are non-executive. There are differences in the responsibilities and functions of boards of directors, for example, legal, social, structural and sectoral differences, any of which may have an impact on the accession of more women to board positions.

Firm sizes are another source of possible bias in the data and conclusions reached. The Fortune 500 companies are generally larger than those in the FTSE 100. Companies enter and leave these indices throughout the year, and hence, if a comparison is made of one year against another, there will be different companies involved, and the same firms are not being compared.

\section{Conclusions and Suggestions for Further Research}

Our data show that whilst there has been an increase in the number of women appointed to non-executive positions recently, the July 2000 figures indicate some slippage, paralleling the situation in the US. The number of executive women directors remains extremely small, albeit matching the US figures.

We suggest that more research needs to be done. A annual database survey should be undertaken of the FTSE 100 companies so that trends can be identified from year to year, and we have started to track this. Whilst this has inherent problems of comparability because of the shifting of companies into and out of the FTSE 100, there would be at least a standard measure of progress. The progress of women directors in SMEs and in the high tech and e-commerce sectors should also be tracked.

Further research is needed into the appointment of women to UK corporate directorships. This requires explanation from the appointing committees and CEOs. We need to understand current reasons for not appointing females. Do CEOs in the UK still believe that there is not a large enough pool of women for director appointments, and if so, what could be done about it? Burke and Mattis (1999) have done such a study in the US and Canada. In the UK, there would be considerable difficulties in gaining access because the CEO and female director population in question is very senior, short of time, and always in demand by journalists and researchers.

Finally, a better understanding is needed of how UK women directors actually contribute to their board's performance, to parallel the study of Fondas and Sassalos (2000), who found that US women directors brought more varied experiences and backgrounds to the board, as well as higher expectations regarding their responsibilities as board members, thereby improving corporate governance. What difference does gender diversity make to UK board decisions regarding corporate reputation, responsibility and profitability? How does the presence of women directors impact corporate practices such as HRM and culture management? If there was evidence that women directors contribute at least as much as their male peers, then that would enhance the case for gender diversity on boards. Only 
with the cooperation of these women directors and their CEOs would we be able to gain enough understanding to present findings which might help the cause of talented women in UK senior management positions to reach FTSE 100 directorships in more than token numbers. Such an understanding could feed into training and development for such potential women business leaders, and into gender diversity change initiatives within organisations. This is a challenge for women in business leadership researchers too.

\section{Acknowledgements}

Acknowledgement is made of assistance by Divindra Bains.

\section{REFERENCES}

Bell, E. (1999) "Tenderness Trap 5", The Observer, 12 December.

Bilimoria, D. (2000a) "Building the Business Case for Women Corporate Directors". In Burke, R.J. and Mattis, M. (eds.) (2000) Women on Corporate Boards of Directors: International Challenges and Opportunities, Kluwer Academic Publishers, Dordrecht, The Netherlands, pp. 25-40.

Bilimoria, D. (2000b), "The Business Case for Women Corporate Directors", Symposium Paper, Academy of Management Annual Conference, Toronto, August

Bilimoria, D. and Piderit, S.K. (1994) Board Committee Membership: Effects of Sex-based Bias. Academy of Management Journal, Vol. 37, No. 6, pp 1453 -1477.

Bilimoria, D. and Huse, M. (1997) "A Qualitative Comparison of the Boardroom Experiences of US and Norwegian Women Corporate Directors", International Review of Women and Leadership, Vol. 3, No. 2, pp. 63-76.

Burgess, Z. (2000) "International Review of Women Directors", Symposium Presentation, Academy of Management Annual Conference, Toronto, August

Burke, R.J. (1997) "Women on Corporate Boards of Directors: A Needed Resource", Journal of Business Ethics, Vol. 16, No. 9, pp. 909-915

Burke, R.J. and Mattis, M. (Eds.) (2000) Women on Corporate Boards of Directors: International Challenges and Opportunities, Kluwer Academic Publishers, Dordrecht, The Netherlands.

Catalyst (1997) 1997 Catalyst Census of Women Board Directors of the Fortune 500, Catalyst, New York.

Catalyst (1999) 1999 Census of Women Board Directors of the Fortune 1000, Catalyst, New York.

Catalyst (2000) Fact Sheet: 2000 Catalyst Census of Women Corporate Officers and Top Earners of the Fortune 5000, Catalyst, New York.

Charan, R. (1998) Boards at Work: How Corporate Boards Create Competitive Advantage. Jossey-Bass, San Francisco.

Daily, C.M., Trevis-Certo, S. and Dalton, D. (1999) "A Decade of Corporate Women: Some Progress in the Boardroom, None in the Executive Suite", Strategic Management Journal, Vol. 20, pp. 93-99.

Daily, C.M., Trevis-Certo, S. and Dalton, D. (2000) "International Experience in the Executive Suite: The Path to Prosperity?", Strategic Management Journal, Vol. 21, No. 4, pp. 515-523.

Dalton, D. R., Daily, C. M., Ellstrand, A. E., and Johnson, J. L. (1998) "Meta-analytic Reviews of Board Composition, Leadership Structure and Financial Performance", Strategic Management Journal, Vol. 10, pp. 269-290.

Fondas, N. and Sassalos, S. (2000) "A Different Voice in the Boardroom: How the Presence of Women Directors affects Board Influence over Management", Global Focus, Vol. 12, No. 2, pp. 13-22.

The Guardian, 23 August 2000, "FTSE 100 directors paid more than £1m last year", p.27. Holton, V.M. (2000) "Taking a Seat on the Board: Women Directors in Britain". In R.J. Burke and M.Mattis (Eds.) Women on Corporate Boards of Directors: International 
Challenges and Opportunities, Kluwer Academic Publishers, Dordrecht, The Netherlands, pp. 145-156.

Ibarra, H. (1992) "Homophily and Differential Returns: Sex Differences in Network Structure and Access in an Advertising Firm", Administrative Science Quarterly, Vol. 37, pp 422-447.

Kuczynski, S. (1999) "If diversity, then higher profits?", HRMagazine, 44 (13), pp. 66-74.

Lorsch, J.W and Mclver, E.A (1989) Pawns or Potentates: A Study of Corporate Governance. Boston: Harvard Business School Press.

MacCanna, L., Brennan, N. and O'Higgins, E. (1999) "National Networks of Corporate Power: An Irish Perspective", Journal of Management and Governance, Vol. 2, pp. 355-377.

Mainiero, L. (1994) "Getting Anointed for Advancement: The Case of Executive Women", Academy of Management Executive, Vol. 8, No. 2, pp. 53-67.

Maitland, A. (2000) "Female-Friendly Policies Fail to Pervade Boardrooms", Financial Times 12 April.

Maznevski, M. L. (1994) "Understanding Our Differences: Performance in Decision-Making Groups with Diverse Members", Human Relations, Vol. 47, No. 5, pp531-552.

McRae, S. (1995) Women at the Top: Progress after Five Years, King-Hall Paper No 2, London: The Hansard Society.

Nicholson, H. (2000) "Jobs for the Girls", The Times, 21 August.

Norburn, D. (1989) "The CEO: A Breed Apart", Strategic Management Journal, Vol 10 pp.1-15.

Ohlott, P.J., Ruderman, M.N. and McCauley, C.D. (1994) "Gender Differences in Managers' Developmental Job Experiences", Academy of Management Journal, Vol. 37, No. 1, pp.46-67.

Oldfield, C. (2000a) "Internet opens door for women bosses", Sunday Times, 16 January.

Oldfield, C. (2000b) "Women battle into the boardroom", Sunday Times, 9 January.

Orser, B. (2000) Creating High-Performance Organizations: Leveraging Women's Leadership, Conference Board of Canada, Ottawa, June.

Ragins, B.R., Townsend, B. and Mattis, M. (1998) "Gender Gap in the Executive Suite: CEOs and Female Executives Report on Breaking the Glass Ceiling", Academy of Management Executive, Vol. 12, No. 1, pp. 28-42.

Rosener, J.B. (1990) "Ways Women Lead", Harvard Business Review, Vol. 68, Nov/Dec, pp. 119-125.

Tavistock/Change Partnership (1999) The Changing Culture of Leadership: Women Leaders' Voices, London: Tavistock Institute.

Varma, A. and Stroh, L.K. (1998) "Gender-based Discrimination in Performance Evaluations: Evidence from Male and Female Samples", $5^{\text {th }}$ International Conference on Advances in Management, Brayford Pool, England, July.

Vinnicombe, S., Singh, V. and Sturges, J. (2000) "Making it to the Top".In R.J. Burke and M.Mattis (Eds.) Women on Corporate Boards of Directors: International Challenges and Opportunities, Kluwer Academic Publishers, Dordrecht, The Netherlands, pp 57-74.

Westphal, J. (1998) "Board Games: How CEOs Adapt to Increases in Structural Board Independence from Management", Administrative Science Quarterly, Vol. 43, pp 511-537.

Westphal, J. and Zajac, E. (1995) "Who Shall Govern ? CEO Power, Demographic Similarity and Director Selection", Administrative Science Quarterly, Vol. 40, pp. 6083. 
APPENDIX 1: FTSE 100 LIST, JULY 2000 (Companies with female directors in bold) Note: ** 13 companies entered in 2000

$3 \mathrm{i}$

Abbey National

Alliance \& Leicester

Allied Domecq

Allied Zurich

Amvescap

Anglo American

Arm Holdings **

Assd. British Foods

AstraZeneca

BAA

BAE Systems (was British Aerospace)

Bank of Scotland

Barclays

Bass

BG

Billiton

Blue Circle Inds

BOC Group

Bookham Technology**

Boots

British Airways

Brit. American Tobacco

BP Amoco

British Sky Broadcasting

British Telecom

Cable \& Wireless

Cadbury Schweppes

Capita Group**

Carlton Communications

Celltech $^{\star *}$

Centrica

CGNU (was CGU)
$\mathrm{CMG}^{* *}$

Colt Telecom

Compass Group

Corus Group**

Daily Mail 'A'

Diageo

Dixons Group

EMAP

EMI Group

Energis

Freeserve Com**

GKN

Glaxo Wellcome

Granada Group

Great Universal Stores

Halifax Group

Hanson

Hays

Hilton Group

HSBC Holdings

Imp. Chemical Industries

Invensys

Kingfisher

Land Securities

Legal \& General

Lloyds TSB Group

Logica** $^{*}$

Marconi (was GEC)

Marks \& Spencer

MiSys

National Grid

National Power

Nycomed Amersham**

Ocean Group**
Old Mutual ${ }^{* *}$

Pearson

$P \& O$

Powergen

Prudential Group

Railtrack Group

Reckitt Benckiser

Reed International

Rentokil Initial

Reuters Group

Rio Tinto

Rolls-Royce

Royal \& Sun Alliance

Royal Bank of Scotland

Sage Group**

J Sainsbury

Schroders

Scottish \& Newcastle

Scot.\& Southern Energy

Scottish Power

Sema Group**

Shell Transport

Smithkline Beecham

South African Breweries

Standard Chartered

TelewestCommunications

Tesco

Unilever (UK)

United News \& Media

United Utilities

Vodaphone Airtouch

Woolwich

WPP 